\title{
Statistical Analysis of Foreign Investments in the Republic of Macedonia 2010-2016
}

\begin{abstract}
Shpresa Syla
ABSTRACT

The aim of this paper is to examine the impact of foreign direct investments (FDI) on the economic growth and the reduction of unemployment, following an empirical research for the Republic of Macedonia. Moreover, the paper investigates the transfer of know-how technology, workforce improvement, integration into the world economy, enhancing the competition in the country's development and the reorganization of domestic firms and difficulties in implementing economic policies. The theoretical and empirical literature suggests dividing opinions and conclusions on the impact of FDI on the economic growth, unemployment and exports. In order to fully understand the flow of FDI in the economic growth through transition countries and their potential economic growth, unemployment and export relations, we have prepared descriptive analyzes, elaborated by charts and tables. In this paper, we have developed empirical models for the Repbulic of Macedonia, a model of FDI impact on the economic growth and unemployment. The analysis uses data from 2012-2017. For the purpose of solving the patterns, the following techniques have been used: broken graphics and regression with the OLS method. The foremost conclusion is to show the relationship between FDI and the economic growth, as well as the relationship between FDI and unemployment in the Republic of Macedonia and FDI relations. Further recommendations will be addressed which aim to improve the country's economic position in attracting foreign investors.
\end{abstract}

Key words: gdp, unemloymend, fdi, export, regression

\section{INTRODUCTION}

The aim of this paper is to examine the impact of FDI on the economic growth and unemployment and export in the Republic of Macedonia. Thus, this paper will address the existing theories in order to create an analytical framework for the relationship between FDI, economic growth export and unemployment. Specifically, the research has the following objectives: To present the theoretical basis for the effect of FDI on the economic growth, export and unemployment with special emphasis on the Republic of Macedonia; To develop a summary of the empirical literature on the impact of FDI on the economic growth, unemployment and exports to Macedonia; Provide a descriptive analysis of trends in foreign direct investment in a transition country such as Macedonia to bring potential growth to the economic growth and unemployment; Develop appropriate empirical models to assess the impact of FDI on the economic growth and unemployment in Macedonia; Give reccommendations to policy makers on the importance of the relationship between FDI and the economic growth in Macedonia. The data will be processed through STAT. The addressed question is: How do foreign direct investments affect Macedonia's GDP, unemployment rate, as well as, export to the country?

\section{METHODOLOGY AND METHODS}

\section{Definition of variables}

The chosen econometric model helps in analyzing and reaching the goal of the paper which aims to find out the result of how foreign direct investments will affect the Republic of 
Macedonia on economic indicators such as the economic growth, unemployment and exports. Even though the model is formulated at a relatively accumulated level, consideration should be given to a diverse range of influences in decision-making to invest in the country. The chosen variables will be clarified and will show us their relationship with foreign direct investments and below the results and the evaluation of the hypotheses will be presented.

\section{Hypotheses}

1.If the foreign direct investments increase, we will have GDP growth in the country.

2.If the foreign direct investments in R.M increase, we will have a decrease in unemployment.

3.With the growth of foreign direct investments, we will have an increase in exports.

Despite some negative effects that FDI may have on host countries, for countries such as Macedonia, it is considered a very important source to help its transition in the market economy.

GDP - Gross domestic product is the dependent variable. The numerous analyzes that have been made on the relationship between the FDI and the economic growth show that FDI has a positive effect on the economic growth of a country, which in our case is in the Republic of Macedonia. The more advanced the country is as far as FDI is concerned, the better the economic growth of the country.

Unemployment - Is also a variable that varies from the FDI, which have a very important impact on the unemployed in the Republic of Macedonia. Foreign Investments will enable job creation and reduction of unemployment. The more foreign direct investments, the unemployment rate of the Republic of Macedonia will be smaller.

Export - In the econometric model the export is presented as a variable that varies by the Foreign Direct Investments.Compilers of multiple policies and analysis of the impact of Foreign Direct Investments in a country's export show that FDI may have significant positive effects on exports.

In the section below, we will have the data for these variables and their analysis over the years. Also, their use in econometric models will give us results to validate the hypotheses.

\section{Econometric assessment: specification of the model}

In order to address the paper's main objectives, the overall focus of this material is more oriented to a quality research. The research begins with observations on the FDI phenomenon, based on existing research and material, and follows with the explanation of its pattern of behavior. Throughout this, however, the study includes quantitative elements, such as statistical data analysis, and an effort to explain progress and provide potential strategies.

This paper will identify the links between FDI on the one hand and the GDP growth, whereas on the other side, it wil identify the links between unemployment and exports. Also, the evaluation and the importance of this relationship will be made. Therefore, we will identify the economic model and analyze all the data related to these variables.

Once the data is collected (the data needed for analysis), it will be analyzed with the help of Stata 10 and Microsoft Excel. In order to fully test the flow of FDI in the economic growth in transition countries and their potential economic growth, unemployment and export, we have prepared descriptive analyzes, elaborated by graphs and tables. 
This section deals with the development of the econometric model in order to represent the relationship between FDI, econometric growth, employment, as well as, export to the Republic of Macedonia. For further research on the impact of FDI on the economic growth, employment and exports, an equation has been established.

This equation is an econometric model Ols wich shows how foreign direct investments affect the rate of unemployment in the country's GDP and exports.

$$
\ln Y=\ln \beta_{2}+\ln \beta_{2}+\ln \beta_{3}+U
$$

Y- represents foreign direct investments

$\boldsymbol{\beta}_{\mathbf{1}}$-represents gross domestic product

$\boldsymbol{\beta}_{\mathbf{2}}$-represents country's export

$\beta_{3}$-represents the unemployment rate in the country.

$\mathbf{U}$ - represents a variable that includes all factors influenced by Foreign Direct Investment

\section{COLLECTION AND DATA ANALYSIS}

In this model, data from the World Bank (http://www.worldbank.org/) and from the State Statistical Office (www.stat.gov.mk) for the period 2012-1027 will be used. From these data, will be analyzed how the export of GDP and the unemployment in the correlation with foreign direct investment have been influenced.

These data will help us make detailed analyzes of how foreign investments have influenced country's GDP. Moreover, if there is a growth or decrease in GDP. As it can be seen from the data, the country's GDP has risen year after year hand in hand with investments until 2015, but in 2016 and 2017 there is drop.

Furthermore, we analyze the rate of unemployment as a very problematic issue in the Republic of Macedonia. Although there is constantly a high trend of stagnation, from 2012-2017 there is still some decrease in unemployment.

The data will be analyzed through STAT and necessary clarifications will be provided as well. Below is the table with the data provided by the World Bank and Statistic Office.

\section{DATA DESCRIPTION}

The data received from the Central Bank and Statistic Office for the period 2012-2017 has been presented in the table above, also the data is presented separately in the last part of the paper(Adddendum). We note an overview of how the indicators, the selected variables and the econometric model reflect over years.

In the first table, we have presented the Gross Domestic Product (GDP) where we estimate that in 2012 it was 466.703 million euros, whereas in 2017 it descreased to 435.652 million euros. In 2015, we have a GDP growth of 558.954 million euros.

The second table shows the data on the unemployment rate in the Republic of Macedonia. From this table it is clear that from 2012 the unemployment was 294.220 until 2017, where there was a decrease of unemployment to 213.648.

Finally, we have a table with the data from Exports of the Republic of Macedonia, which also shows us a clear picture of the growth of exports over the years. Exports in Macedonia during 2012 were 3.124.0. 


\begin{tabular}{|llll}
\hline Year & Gdp & Unemloymend & Export \\
\hline $\mathbf{2 0 1 2}$ & 466.703 & 294.220 & 3.124 .0 \\
$\mathbf{2 0 1 3}$ & 501.981 & 275.225 & 3.235 .2 \\
$\mathbf{2 0 1 4}$ & 527.632 & 265.370 & 3.746 .6 \\
$\mathbf{2 0 1 5}$ & 558.954 & 249.000 & 4.087 .6 \\
$\mathbf{2 0 1 6}$ & 435.564 & 225.049 & 4.329 .3 \\
$\mathbf{2 0 1 7}$ & 435.652 & 213.648 & 1.324 .7 \\
\hline
\end{tabular}

In 2015 and 2016 there will also be an increase in exports that will reach up to 4.329 .3 million euros, and in 2017 we have a drastic decrease to 1.324 .7 million denars.

CALCULATION AND RESULTS OF THE ECONOMETRIC MODEL

In order to analyze the impact of foreign direct investments in the Republic of Macedonia, as it was mentioned above, the following econometric model has been used:

$$
\ln Y=\ln \beta_{2}+\ln \beta_{2}+\ln \beta_{3}+U
$$

For the calculation of this model, we will use the Stata program which will help us calculate the direct foreign influences on the economic growth, unemployment and exports of the Republic of Macedonia.Data from the State Statistical Office and the World Bank will be put on data editor, then we will put the data into the calculations for commenting on the data.

Below an econometric model is obtained, where all the necessary operations are performed and data is calculated by linear regression through Stat:

\section{$Y=9.510644-0.569644 X+0.6153073+U$}

Given the results of this model, we conclude that data are appropriate $61.53 \%$ and this is seen from the indicator or the determination coefficient: R-squared $=0.6153$; this coefficient also indicates that the independent variable is explained by $61.53 \%$ dependent variables. Also, based on the results, we note that the residual (U variable) equals Residual $=0.029160009$. Another data which is ascertained by the results of calculating the econometric model is the standard error which for the GDP variable is 7.286516, the unemployment is 0.3499297 , for the export variable is 2983924.T-statistics for the econometric variables of origin are: GDP $(\mathrm{t})=$ 0.76 unemployment $\mathrm{t}=0.19$ export $\mathrm{t}=1.80$

Based on the originally calculated econometric model, calculated with Stata 10 as follows:

$$
Y=9.510644-0.569644 X+0.6153073+0.6153
$$

According to this, we will give an explanation about the result that emerges from the model and then based on these we will provide conclusions in the final part.

From the linear regression, we can clearly see that:

1. The unemployment variable shows that with the stagnation of the investments, the number of unemployed in the country will increase in different companie. So, if the 
investments remain at the same level, meaning that they will not grow or will not be reduced, the unemployment will rise roughly to $0.569644 X \%$.

2. When the investments will increase by 1 euro, then exports will rise to $0.6153073 \%$, denoting investors with investments that will make export growth, goods and services in foreign countries.

3. $\mathrm{r}^{2}$ which measures data's adaptability is 0.6153 or put otherwise the adaptability is $61.53 \%$ which means that $61.53 \%$ of the data are included, and only $38.47 \%$ of the data are not included in the econometric model.

4. Based on the model, we confirm the hypotheses. In other words, the increase in foreign direct investmens affects the growth of exports.

\section{CONCLUSIONS AND RECOMMENDATIONS}

This research was aimed at testing our hypotheses that foreign direct investments(FDI) positively affect the GDP's growth, reduce unemployment and export growth in the Republic of Macedonia. By reviewing the literature, the methodology used, the econometric model specification, data collection, data analysis, the calculation of the econometric model, an accurate answer to the research questions was assumed. Considering the results which were gained from the calculation of the econometric model, the hypotheses are accurate and the grow of the FDI inflow has a significant impact on GDP's growth, as well as, in the reduction of unemployment and the growth of exports to Macedonia.

Finally, the Government of the Republic of Macedonia can encourage the development of particular geographic areas within the country, which represent areas with great investment opportunities in the country, in order to make the country more attractive. Such areas are industrial or turist sites (such as coastal areas). The development of these areas may require large investments and resources, however pilot projects can initially be initiated, which can be implemented more broadly after their operation.

\section{BIBLIOGRAPHY}

Statisticki pregled: Nacionalna ekonomija I finansii, STATISTICAL REVIEW: Nationay economy and Finances

Dunning, J. H. (1994), “The Prospects for Foreign Direct Investment in Central and Eastern Europe.” in Buckley, P.J and Ghauri, P. N. (eds.), The Economics of Change in East Europe - its Impact on International Business, UK: Academic Press Ltd.

Bogun, A.L(2009), Strategic Fit for Foreign Direct Investment in Transition Economies, International Journal of Business and Economics

Moura, R and Forte, R (2010), The Effects of Foreign Direct Investment on Host Country Economic Growth Theory and Empirical Evidence, working paper (FEP)- Universidade do Porto, 290, p.1-32. Ebsco Host (Пристапено на 30.05.2011)

Abor, J. and Harvey, K.S. (2008), Foreign direct investment and employment: host country experience, Macroeconomics and finance in emerging market economies

Kornecki, L. and Rhoades D. (2007), How FDI Facilitates the Globalization Process and Stimulates Economic Growth In CEE, Journal Of International Business Research

Marián Dinga: The Impact of Territorially Concentrated FDI on Local Labor Markets:

Evidence from the Czech Republic (2008)

PALÁT, M.: The impact of foreign direct investment on unemployment in Japan. Acta univ. agric. et silvic. Mendel. Brun., 2011, LIX, No. 7, pp. 261-266

www.stat.gov.mk/Publikacii/2.4.9.12.pdf

http://www.ihi-zittau.de/de/dnl/fdi_in_cee.813.pdf

http://unctad.org/en/docs/wir2002_en.pdf 
http://www.nber.org/chapters/c6532.pdf

http://www.aabri.com/LV11Manuscripts/LV11096.pdf

http://www.mendelu.cz/dok_server/slozka.pl?id=51329;download=88549

http://www.cerge-ei.cz/pdf/wp/Wp348.pdf 